Chirurgia (2017) 112: 394-402

No. 4, July - August

Copyright@ Celsius

http://dx.doi.org/10.21614/chirurgia.112.4.394

\title{
New Language and Old Problems in Breast Cancer Radiotherapy
}

\author{
Ion Christian Chiricuță \\ AMETHYST Radiotherapy Center, Otopeni, Romania
}

Corresponding author:

Professor Ion Christian Chiricuță AMETHYST Radiotherapy Center

Otopeni, Romania

E-mail: kirikuta@gmx.de

\section{Rezumat \\ Un nou limbaj și problemele vechi în radioterapia cancerului mamar}

$\mathrm{Cu}$ toate îmbunãtãțirile şi progresele realizate în special în radioterapie efecte secundare acute şi tardive sunt din pãcate încã prezente. Progresele realizate în ultimele decenii şi în special în ultimii ani au creat posibilitatea introducerii unor noi standarde în tratamentul complex al cancerului mamar. Noi soluții sunt cãutate şi progresele în tehnicile noi de iradiere permit şi faciliteazã progresele dorite. Apariția unor ghiduri internaționale creazã noi oportunitãți de îmbunãtãțire a rezultatelor posibile. Tranziția de la o radioterapie în 2 dimensiuni la radioterapia conformaționalã (în 3 dimensiuni) a fost un proces lung dar care acuma se considerã încheiat. Radioterapia cu intensitate modulatã indiferent de tehnica utilizatã (Rapid Arc, VMAT sau Tomotherapy) are ca scop reducerea efectelor secundare atât de temute ale tehnicilor clasice ca şi: radionecroza cutanatã, limfedemul brațului, fibrozã pulmonarã, esofagitã radicã, fracturile la nivelul coastelor, plexita brahialã şi infarctul miocardic. În ciuda progreselor realizate incidența anumitelor efecte secundare a fost mult redusã dar este încã prezentã. Doar îmbunãtãtirea metodelor de calcul al planului de iradiere, de verificare a planurilor de iradiere cu ajutorul fantomelor utilizate în dozimetrie şi îmbunãtãțirea controlului aplicãrii zilnice a planului de iradiere fac posibilã îmbunãtãtirea rezultatelor finale. Introducerea de noi procedee ca şi procedeul ganglionului santinelã (SNP), iradierea parțialã a sânului (PBRT) şi reconstrucția imediatã prin implant cu silicon au creat necesitatea introducerii de noi concepte în privința delimitãrii volumelor țintã utilizate în radioterapie. Astfel definiția volumului țintã corespunzãtor tumorii macroscopice şi microscopice se bazeazã pe metodologii noi ca 
examinarea PET/CT, examinarea RMN cu nanoparticule vor avea un impact asupra delimitãrii volumelor corespunzatoare dar şi asupra tehnicilor utilizate în radioterapie. "Limbajul nou comun în terapia cancerului" este prima etapã necesarã pentru îmbunãtãțirea rezultatelor finale dorite la pacienți.

Cuvinte cheie: cancer mamar, volum țintã, limfedem, radionecrozã, radioterapie

\begin{abstract}
New developments in breast cancer radiotherapy make possible new standards in treatment recommandations based on international guidelines. Developments in radiotherapy irradiation techniques from 2D to 3D-Conformal RT and to IMRT (Intensity Modulated Arc Therapy) make possible to reduce the usual side effects on the organs at risk as: skin, lung, miocard, bone, esophagus and brahial plexus. Dispite of all these progresses acute and late side effects are present. Side effects are as old as the radiotherapy was used. New solutions are available now by improving irradiation techniques. New techniques as sentinel node procedure (SNP) or partial breast irradiation (PBRT) and immediate breast reconstruction with silicon implants (IBRIS) make necessary new considerations regarding the target volume delineations. A new language for definition of gross tumor volume (GTV), clinical target volume (CTV) based on the new diagnostic methods as PET/CT,nonaparticle MRI will have real impact on target delineation and irradiation techniques. "The new common language in breast cancer therapy" would be the first step to improve the endresults and finally the quality of life of the patients.
\end{abstract}

Key words: breast cancer, target volume, lymfedema, radionecrose, radiotherapy

\section{The Evolution of the Locoregional Treatment Concept of Breast Cancer}

The breast cancer surgery was from the beginning an ablative one, determined by the advanced locoregional stage of the patients presenting to the surgeon. The American surgeon William Stewart Halsted introduced and practiced since 1882 the radical mastectomy in the breast cancer treatment (Fig. 1). The radical mastectomy was aimed to remove the breast and the axillary lymph nodes, including the removal of both pectoral muscles (Fig. 2). Immediately occurred also the side effects due to the radical surgery, namely the limitation of the functionality of the arm on the operated breast side, lymphedema of the arm and the loss of the breast. Several new procedures as the internal mammary lymph nodes dissection on the affected side and the supraclavicular lymph nodes removal were attempts in pre- venting local recurrence in the mammary gland tributaries chain.

The Halsted mastectomy was maintained until 1970 when the Italian surgeon Umberto Veronesi from Milano initiated a limited surgery, namely the extirpation of only the tumor and the affected quadrant for cases in early stage of the disease (1). The axillary dissection and the internal mammary nodal chain dissection for the centrally located tumors or those located in lateral quadrants of the breast, but with axillary invasion, continued to be a target volume for the surgical act. The high frequency of local recurrences, namely in the chest wall, the axillary space, the parasternal space and the supraclavicular lymph nodes lodge made it necessary to find a new solution to increase the loco-regional tumor control after surgery. The radiotherapy became the most important treatment for the reduction of locoregional relapse. 


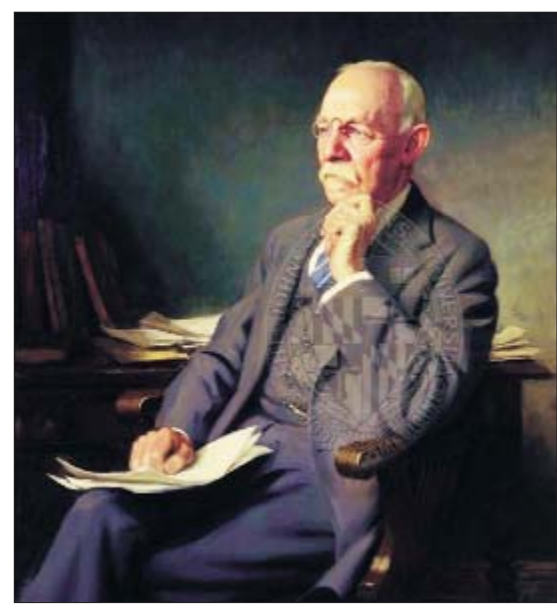

Figure 1. William Stewart Halsted (1882) (2)

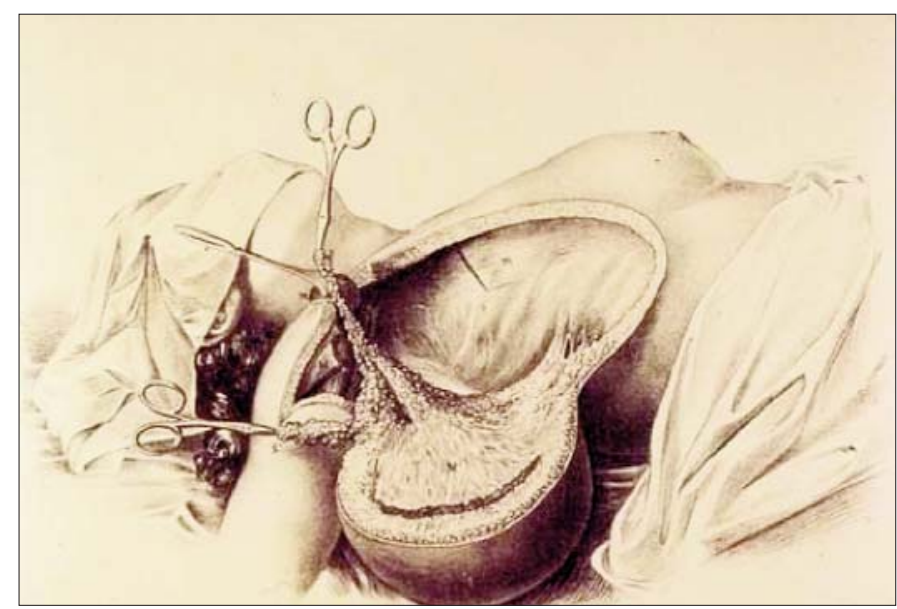

Figure 2. 1882 The Halsted operation principle (4)

\section{The Beginnings of Radiotherapy in Breast Cancer Treatment}

The X - Ray radiations discovery by Wilhelm Konrad Roentgen in 1895 and their application to external radiation treatment of malignant tumors or as implant (brachytherapy) were applied in the initial years with the hope to improve the local tumor control (Fig. 3). Doctor Chicotot from Paris painted himself during the application of local radiation treatment with a $\mathrm{X}$ - ray tube in 1907 (Fig. 4).
Immediately appeared the side effects of radiant treatment too: lymphedema of the arm and the radionecrosis (Figs. 5-8).

\section{Sentinel Node Concept and Conservative Treatment of the Axilla}

Since 1992 by recognizing the sentinel node concept described by Ramon Cabanas from Paraguay, in his doctoral thesis in 1965 in Asuncion, and subsequently published in Cancer in 1977 (8), the method for designation

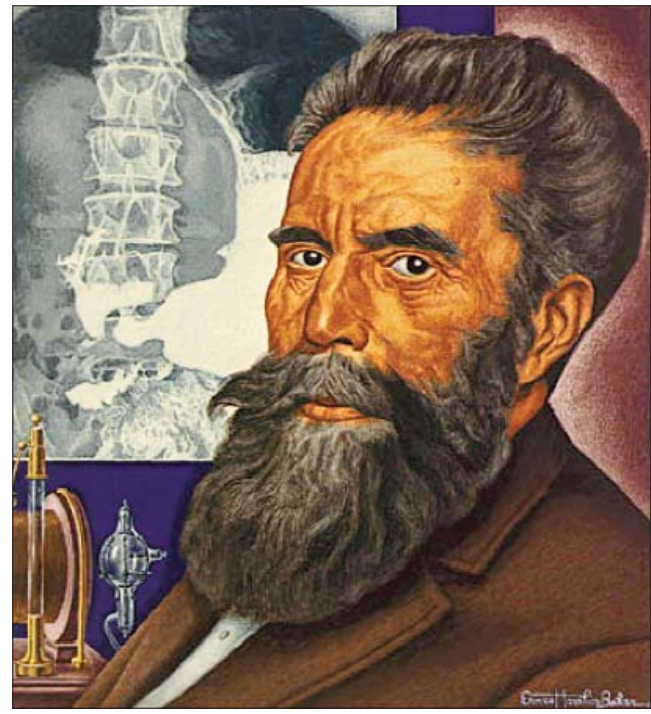

Figure 3. Wilhelm Konrad Röntgen (1895) (3)

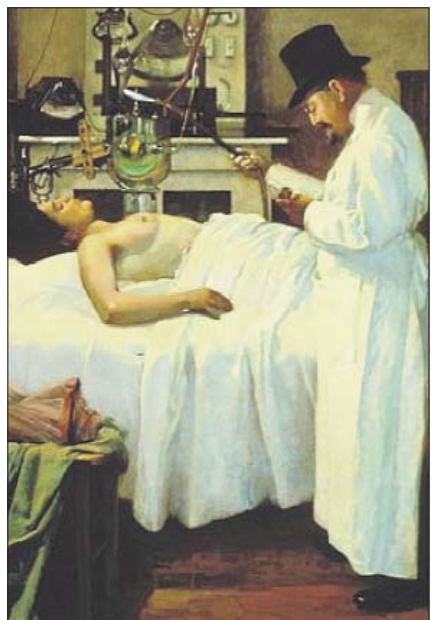

Figure 4. 1907 Doctor CHICOTOT first attempt for breast irradiation (Paris) (5) 


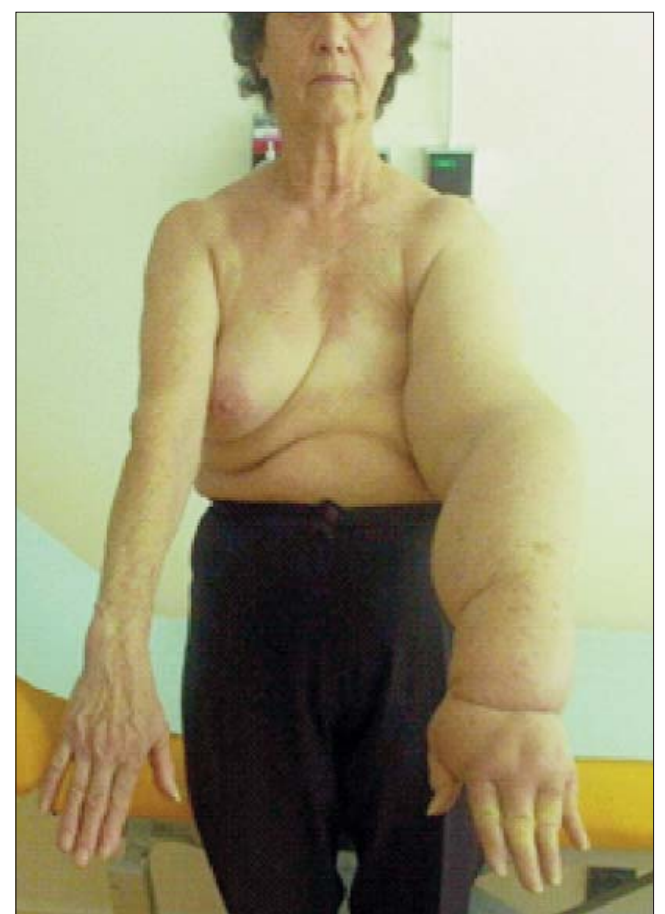

Figure 5. Lymphedema of the arm, after axillary dissection followed by radiation (6)

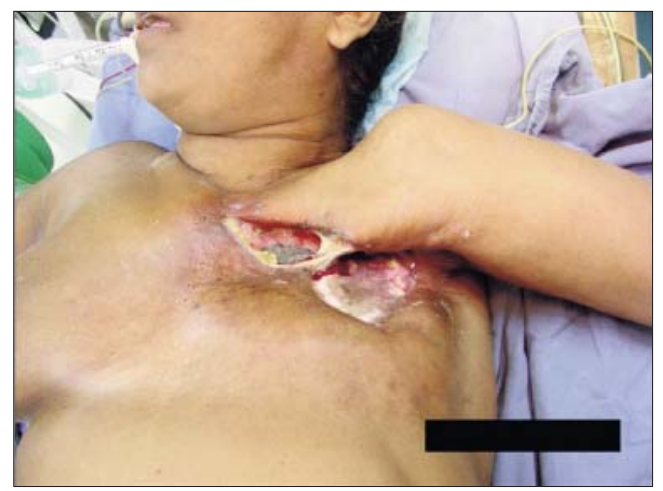

Figure 7. Radionecrosis chest wall following mastectomy and external radiation therapy (7)

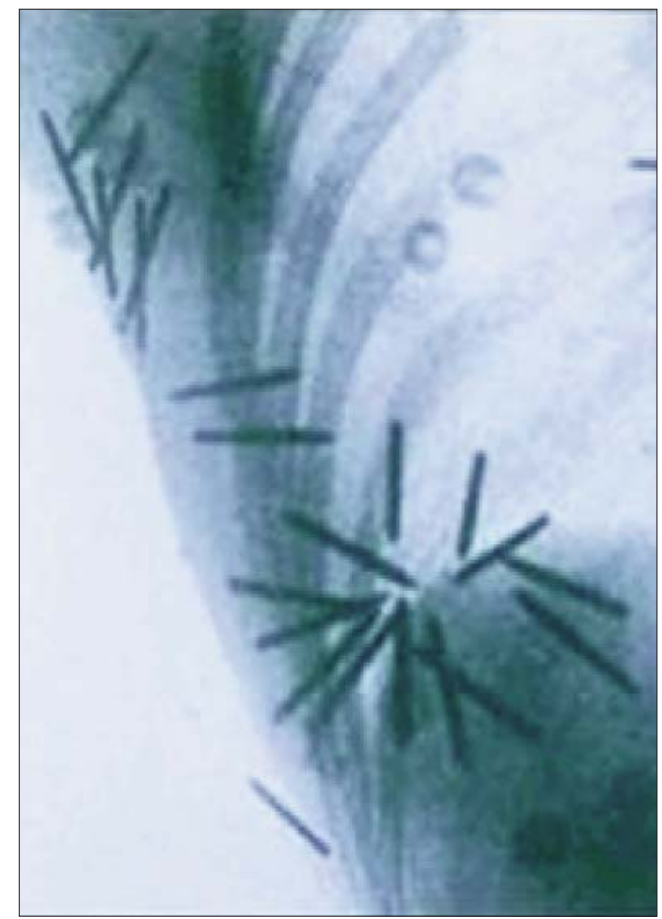

Figure 6. Radium implants in breast treatment (Sciencephotolibrary)

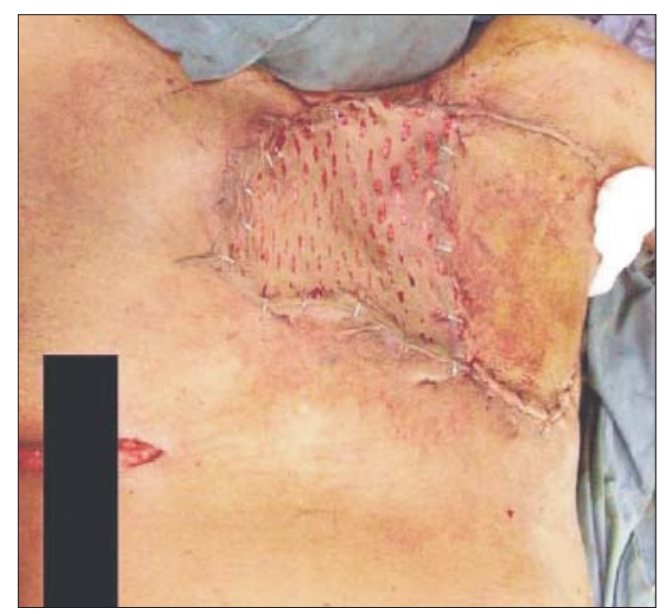

Figure 8. Plastic surgery repair the defect by using the latissimus dorsi transplant (7)

study published by the Amsterdam Group (9) where in $29 \%$ of patients a different treatment decision was made based on the status described by the IMC located SN lymph nodes. The indication of adjuvant chemotherapy and radiotherapy was based on the only involvement of the IMC positive nodes in axillary uninvolved nodes. 


\section{NCCN Guidelines and Treatment of Breast Cancer}

The progress in the imaging investigations as CT, MRI and PET / CT and based on the histological and the immunohistochemistry data of the primary tumor makes it now possible the correct mammary cancer staging and also facilitates through the decision of a tumor board the indication of the properly indicated adjuvant treatment.

For the loco-regional radiotherapy treatment in breast cancer patients, in the Radiotherapy Center AMETHYST, we use the recommendations of the NCCN (National Comprehensive Cancer Network), (10) as reproduced below (Fig. 9).

\section{The Definition of Target Volumes and Structures with Radiation High Risk}

Progresses made in the radiation therapy have made possible the application of the doses, indicated in the recommendations of the different societies, to volumes anatomically well defined. The risk organs as lung, myocardium, axillary vessels and supraclavicular region and the brachial plexus can be necessary or appropriate protected to irradiate them with doses which can induce undesirable side effects.

A representation of these structures and of the target volume to be irradiated with minimum curative dose 50 Gy / 2 Gy is shown in the Fig. 10.

\section{The Techniques with Modulated Intensity in the Breast Cancer Radiotherapy}

Over the past 30 years the irradiation techniques and the possibilities of application greatly developed. The definition and use of well defined target volumes for breast cancer patients were first done at the Radiation Oncology Department from Würzburg University and published (13, 14, 15). The irradiation with large fields that included also sensitive organs as axillary vessels, lung parenchyma or myocardial tissue were abandoned and new radiotherapy techniques as conformal radiotherapy (3D-RT) and the radiation with modulated intensity (IMRT) under its various alternatives as VMAT (modulated arc Therapy), Rapid arc, Tomo Therapy make

\section{NCCN $\begin{aligned} & \text { National } \\ & \text { Comprehensive } \\ & \text { Cancer }\end{aligned}$ NCCN Guidelines Version 1.2012 \\ Network ${ }^{2}$ Invasive Breast Cancer}

LOCOREGIONAL TREATMENT OF CLINICAL STAGE I, IIA, OR IIB DISEASE OR T3, N1, M0

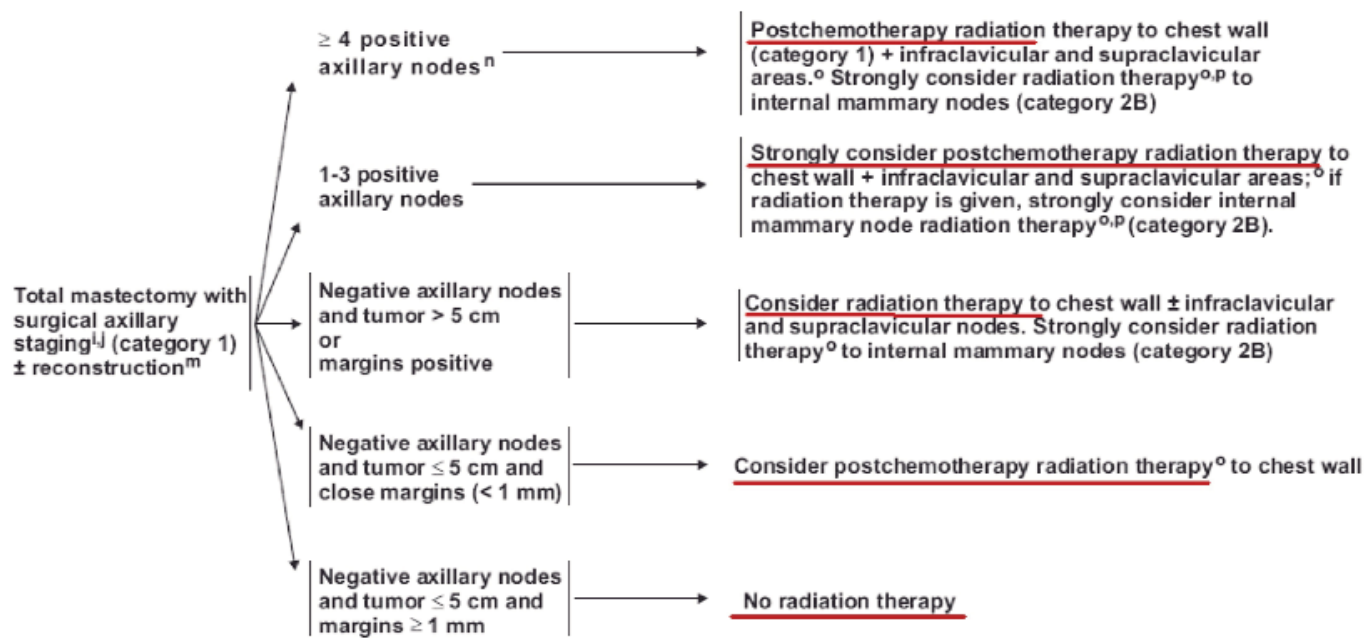

Figure 9. 


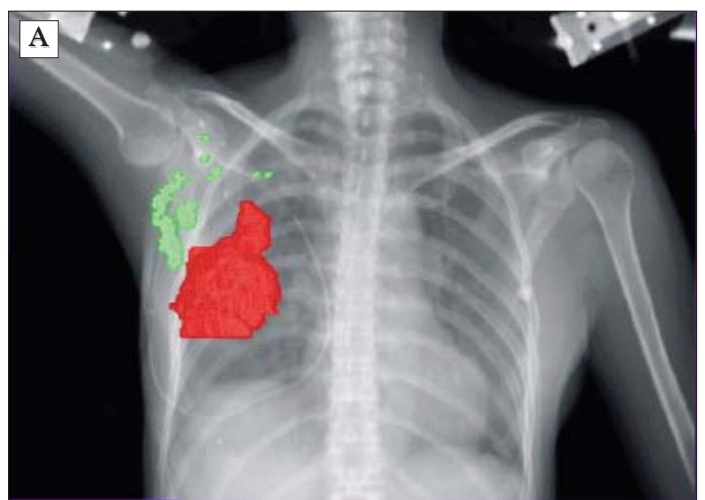

Figure 10. (A) Tumor bed (red) and axillary lymph nodes (green) (11); (B) The remaining breast (gray) and the breast dependent nodal areas (axilla level I-violet, axilla level II-blue) and supraclavicular nodes (brown) (12)

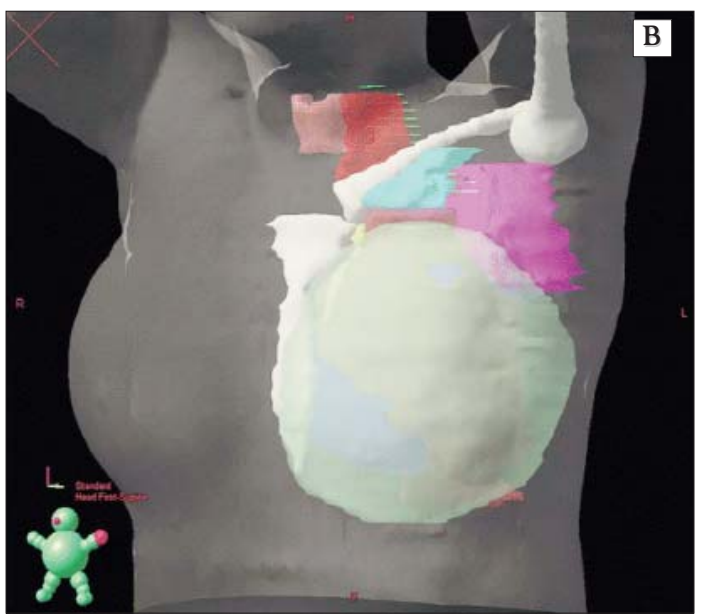

\section{The Postoperative Radiotherapy after Breast Conservative Surgery}

The patient number 1 . Adjuvant radiotherapy of the remaining breast with 50 Gy in 25 frac- $^{-}$ tions of 2 Gy (the thick green line in the left image) and with the boost of tumor bed with 16 Gy in 8 fractions (area marked with green in the right image). The axillary vessels marked with red are protected because the 3 excised sentinel lymph nodes were not invaded by the tumor. The clinical result on the last treatment day shows a light hyperpigmentation of the skin (Fig. 11).

\section{The External Radiotherapy in Locally Advanced Breast Cancer}

In case of locally advanced tumors when any surgery and the response to chemotherapy or hormonal treatment were not satisfactory, the loco-regional radiation therapy remains the only possible solution. Even without a IMRT technique it is possible to achieve a tumor control as can be seen in the case of the 82 years patient who came in our service in the clinic in Limburg.

The patient number 2. Locally advanced tumor, bleeding and with infiltration of the sternum and the internal mammary lymph nodes (Fig. 12). 

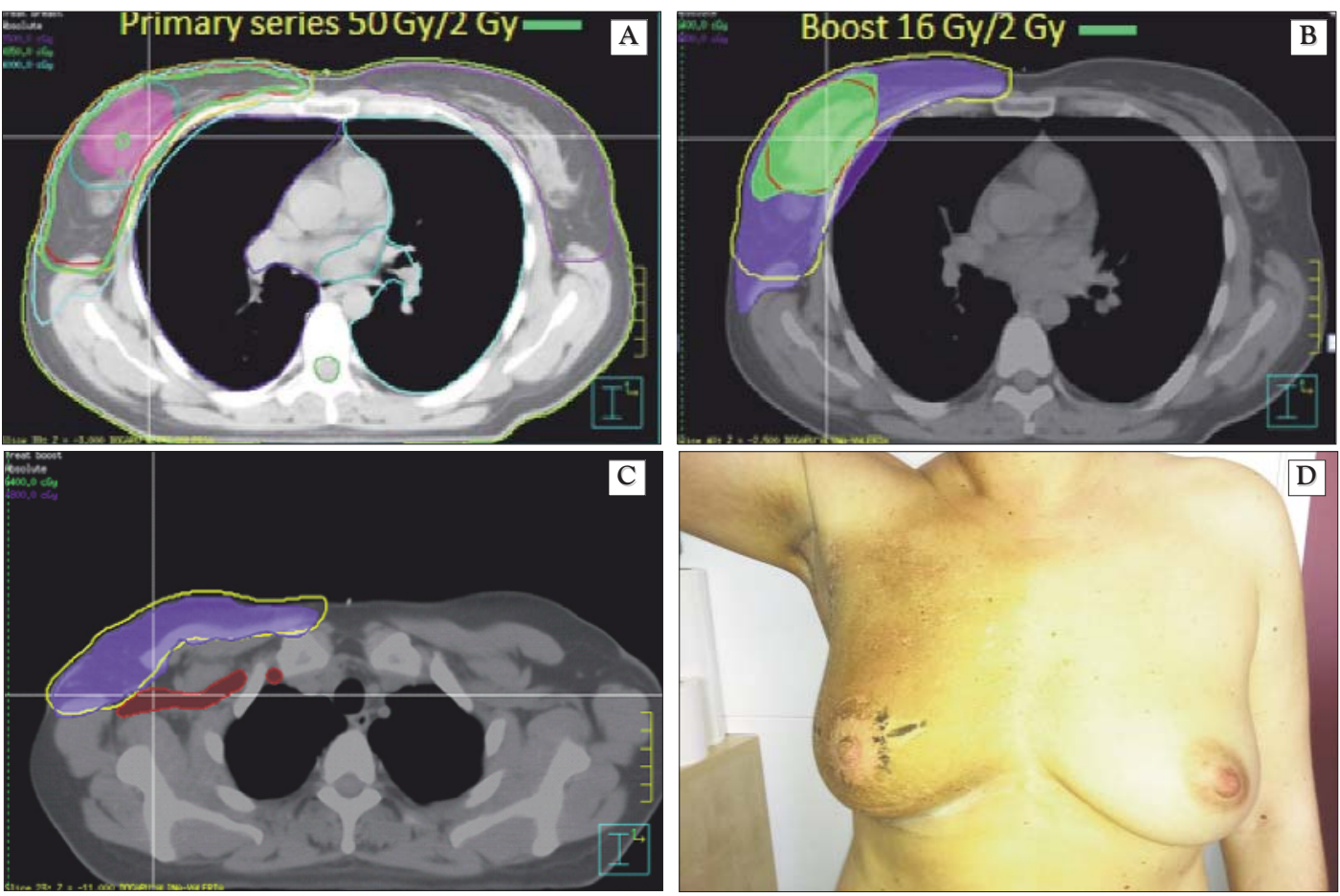

Figure 11. Patient 1 at the end of the treatment
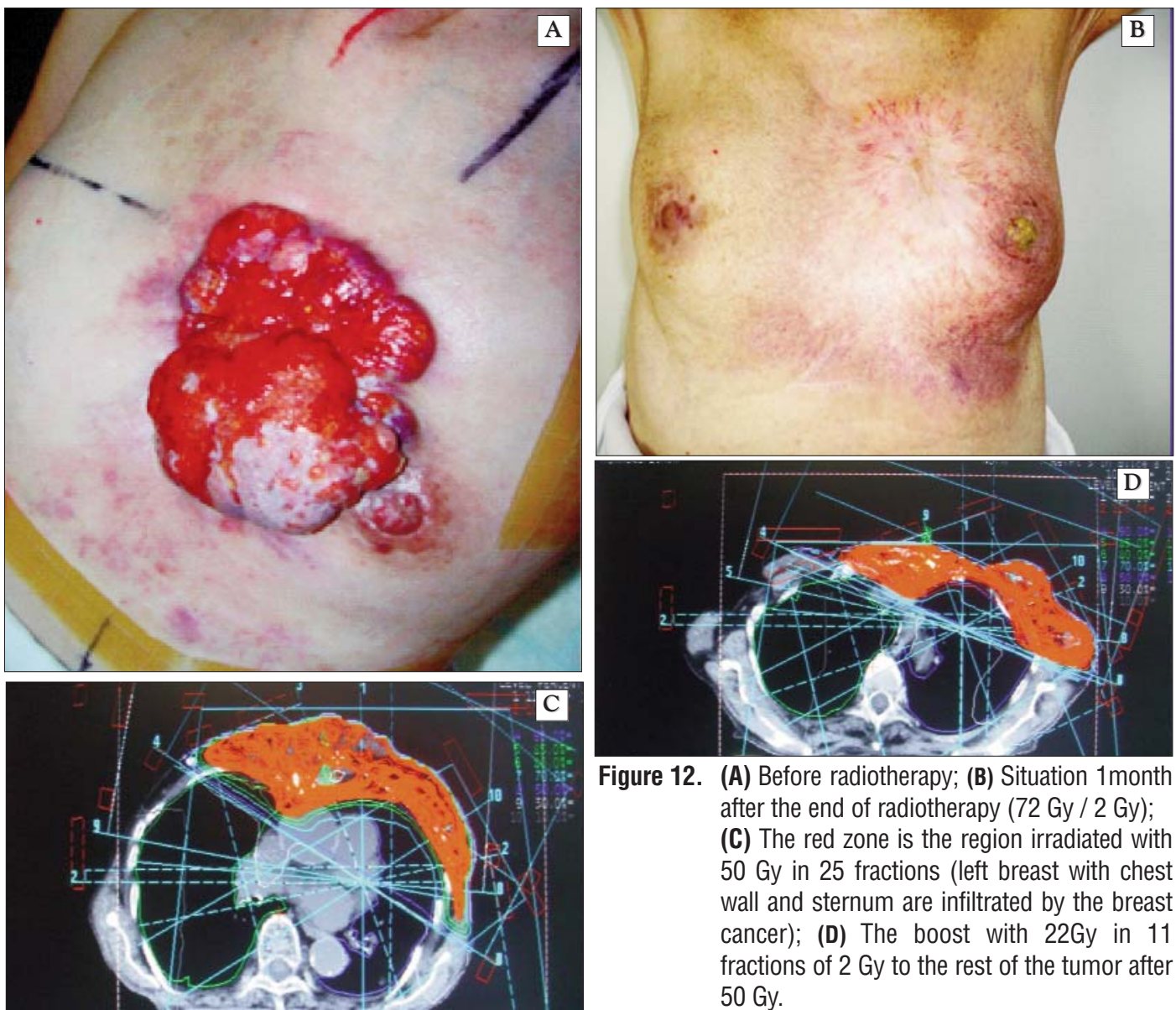

Figure 12. (A) Before radiotherapy; (B) Situation 1month after the end of radiotherapy (72 Gy / 2 Gy);

(C) The red zone is the region irradiated with 50 Gy in 25 fractions (left breast with chest wall and sternum are infiltrated by the breast cancer); (D) The boost with 22Gy in 11 fractions of 2 Gy to the rest of the tumor after 50 Gy. 
Using the VMAT technique, the myocardial protection and especially the left circumflex coronary artery protection is possible, in case of tumors located in the remaining breast and requiring adjuvant radiotherapy.

\section{The Postoperative Radiotherapy with Myocardial and Costal Rebord Protection}

Patient number 3 . The adjuvant breast radiotherapy left-sided (red area) for a patient with macromasty and to which a boost of tumor bed was required. The myocardium and especially the left circumflex coronary artery is close to the chest wall. The remaining mammary gland was irradiated with 50 Gy in 25 fractions and the tumor bed (the blue area) was irradiated with additional 16 Gy in 8 fractions. A protection of the myocard was possible (the isodose of 40 Gy is at the costal arch - green line) (Fig. 13).

\section{The Postoperative Radiotherapy Immediately after Silicone Implant}

In cases where the amputated breast is rebuilt using the silicone implant or the expandable one, the radiation therapy aims to destroy the left tumor cells after the subcutaneous mastectomy. The prostheses used today have never been tested itself by an irradiation applied in clinical routine. Therefore the responsibility of the clinical result after the radiotherapy in case of immediate reconstruction remains by the surgeon and the radiotherapist performing the treatment.

The patient number 4 . The radiation of the left breast done in the case of a young patient to which an immediate breast reconstruction with silicone implant was performed. A total dose of 50 Gy in 25 fractions of 2 Gy was applied (green line) (Fig. 14).

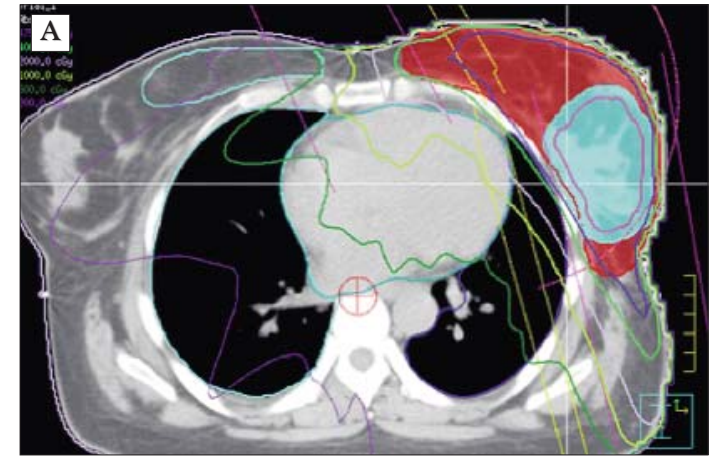

Figure 13.

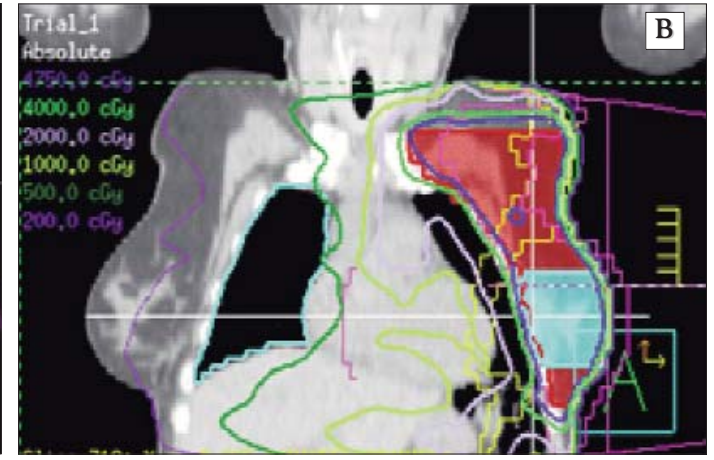

\begin{abstract}
$$
\text { (1) }
$$
\end{abstract}

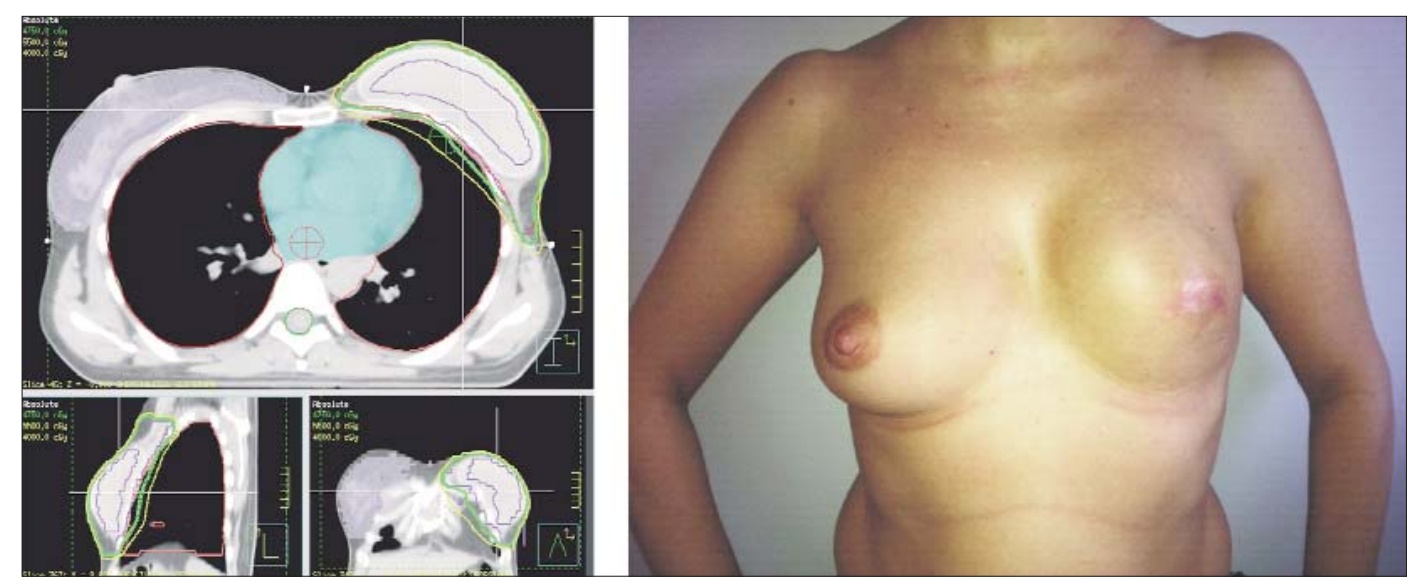

Figure 14. The dose distribution of the irradiation plan for a postoperative adjuvant treatment after immediat silicone implant (left) and the clinical result at the end of the radiotherapy (right) 


\section{Conclusions}

Progresses in imaging and in the used equipment in the external radiation treatment make possible the application of an individualized treatment by a homogeneous dose applying to the target volumes with microscopic and macroscopic disease to improve the control of the disease in the breast remnants or of the chest wall and in the areas of axillary nodes, the internal mammary lymph nodes and in the supraclavicular lymph nodes. The side effects to fear as lymphedema, pulmonary fibrosis or late myocard side effects as myocardial fibrosis or infarction caused by a deficient technical irradiation were reduced significantly.

\section{References}

1. Veronesi U, Cascinelli N, Mariani L, Greco M, Saccozzi R, Luini A, et al. Twenty-year follow-up of a randomized study comparing breast-conserving surgery with radical mastectomy for early breast cancer. N Engl J Med. 2002;347(16):1227-32.

2. William Stewart Halsted, oil on canvas, by Thomas C. Corner, The Alan Mason Chesney Medical Archives of the Johns Hopkins Medical Institutions.

3. Wilhelm Conrad Roentgen, ETH-Bibliotek Zuerich, Bildarchiv Public Domain via Wikimedia Commons.

4. The Halsted operation, from Kuerer HM: Kuerer's Breast Surgery
Oncology. The McGraw-Hill Companies.

5. Georges Chicotot: The Attempt to Treat Cancer with X-Rays, 1907, Musee de l'Assistance Publique, Hopitaux de Paris.

6. Becker C. Treatment of Breast Cancer-Related Lymphedema Using Combined Autologous Breast Reconstruction and Autologous Lymph Node Transplantation. In: Breast Reconstruction - Current Perspectives and State of the Art Techniques. Ed by Aldona J. Spiegel; 2013.

7. Iyer S, Balasubramanian D. Management of radiation wounds. Indian J Plast Surg. 2012;45(2):325-31. doi: 10.4103/0970-0358. 101311.

8. Cabanas RM. An approach for the treatment of penile carcinoma. Cancer. 1977;39(2):456-66.

9. Estourgie SH, Tanis PJ, Nieweg OE, Valdés Olmos RA, Rutgers EJ, Kroon BB. Should the hunt for internal mammary chain sentinel nodes begin? An evaluation of 150 breast cancer patients. Ann Surg Oncol. 2003;10(8):935-41.

10. Gradishar W, Salerno KE. NCCN Guidelines Update: Breast Cancer. J Natl Compr Canc Netw. 2016;14(5 Suppl):641-4.

11. Dinniwell R. Radiotherapy for breast cancer - Slideshare https://de.slideshare.net/fovak/dinniwell

12. Kirova YM, Castro Pena P, Dendale R, Servois V, Bollet MA, FournierBidoz N, et al. Simplified rules for everyday delineation of lymph node areas for breast cancer radiotherapy. Br J Radiol. 2010;83(992):6836. doi: 10.1259/bir/ 28834220. Epub 2009 Dec 17.

13. Kiricuta IC, Willner J, Buth KJ. CT - Bestrahlungsplanung beim Mamakarzinom. In: Bohndorf W. und Richter J. Computertomographie und Bestrahlungsplanung in der Radioonkologie. Biermann Verlag. 1992.

14. Kiricuta IC, Götz U, Schwab F, Fehn M, Neumann HH. Target volume definition and target conformal irradiation technique for breast cancer patients. Acta Oncol. 2000;39(3):429-36.

15. Kiricuta IC. Target volume delineation in breast cancer conformal radiotherapy. In: Gregoire V., Scalliet P., Ang K. K. Chapter 8 in: Clinical Target Volume in Conformal and IMT. A Clinical Guide to Cancer Treatment. Springer Verlag 2004. 